\title{
Apps for applying to ObGyn residency programs in the era of virtual interviews
}

\author{
The pandemic has required program and student flexibility \\ and innovation. These authors offer help for navigating \\ the process.
}

Farida Nentin, MD, and Katherine T. Chen, MD, MPH

T he coronavirus disease 2019 (COVID19) pandemic has upended the traditional 2020-2021 application season for ObGyn residency programs. In May 2020, the 2 national ObGyn education organizations, the Association of Professors of Gynecology and Obstetrics (APGO) and Council on Resident Education in ObGyn (CREOG), issued guidelines to ensure a fair and equitable application process. ${ }^{1}$ These guidelines are consistent with recommendations from the Association of American Medical Colleges (AAMC) and the Coalition for Physician Accountability. Important recommendations include:

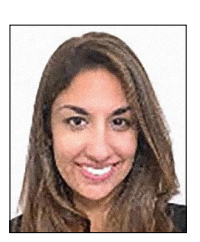

Dr. Nentin is Program Director and Assistant Professor of Obstetrics, Gynecology, and Reproductive Science, Icahn School of Medicine at Mount Sinai, New York, New York.

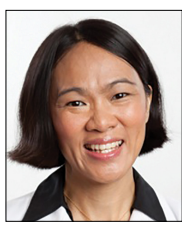

Dr. Chen is Vice-Chair of Ob-Gyn Education for the Mount Sinai Health System and Professor of Obstetrics, Gynecology, and Reproductive Science and Medical Education, Icahn School of Medicine at Mount Sinai. She is an OBG MANAGEMENT Contributing Editor.

Dr. Nentin reports no financial relationships relevant to this article. Dr. Chen reports being an advisory board member for and receiving royalties from UpToDate, Inc.
- limiting away rotations

- being flexible in the number of specialtyspecific letters of recommendation required

- encouraging residency programs to develop alternate means of conveying information about their curriculum.

In addition, these statements provide timing on when programs should release interview offers and when to begin interviews. Finally, programs are required to commit to online interviews and virtual visits for all applicants, including local students, rather than in-person interviews.

Here, we focus on identifying apps that students can use to help them with the application process-apps for the nuts and bolts of applying and interviewing and apps to learn more about individual programs.

Students must use the Electronic Residency Application Service (ERAS) platform from AAMC to enter their information and register with the National Resident Matching Program (NRMP). Students also must use the ERAS to submit their applications to their selected residency programs. The ERAS platform does not include an app to aid in the completion or submission of an application. The NRMP has developed the MATCH PRISM app, but this does not allow students to register for the match or submit their rank list. To learn about how to schedule interviews, residency programs may use 
TABLE 1 Recommended apps to aid with ObGyn residency applications and interviews

\begin{tabular}{|c|c|c|c|}
\hline App & Platform & Important features & Caveats \\
\hline $\begin{array}{l}\text { The MATCH PRISM app, } \\
\text { by the National Resident } \\
\text { Matching Program (NRMP) }\end{array}$ & $\begin{array}{l}\text { - Free app available for iOS } \\
\text { and Android }\end{array}$ & $\begin{array}{l}\text { - Has residency match } \\
\text { schedule of events } \\
\text { - Creates personal lists of } \\
\text { programs } \\
\text { - Syncs with Outlook which } \\
\text { allows for tracking applica- } \\
\text { tion and interview schedule } \\
\text { - Allows user free-text notes } \\
\text { about program }\end{array}$ & $\begin{array}{l}\text { - Cannot schedule inter- } \\
\text { views with programs } \\
\text { - Cannot submit NRMP } \\
\text { rank list }\end{array}$ \\
\hline Thalamus & $\begin{array}{l}\text { - Free app available for iOS } \\
\text { and Android }\end{array}$ & $\begin{array}{l}\text { Allows online scheduling } \\
\text { of interviews in real time } \\
\text { - Streamlines communica- } \\
\text { tion between program and } \\
\text { applicant } \\
\text { - Manages confirmations, } \\
\text { rescheduling, waitlists, and } \\
\text { cancellations }\end{array}$ & $\begin{array}{l}\text { - Cannot use software to } \\
\text { conduct virtual interviews }\end{array}$ \\
\hline
\end{tabular}

one of the following sources: ERAS, Interview Broker, or Thalamus. Moreover, APGO/ CREOG has partnered with Thalamus for the upcoming application cycle, which provides residency programs and applicants tools for application management, interview scheduling, and itinerary building. Thalamus offers a free app.

This year offers some unique challenges. The application process for ObGyn residencies is likely to be more competitive, and students face the added stress of having to navigate the interview season:

- without away rotations (audition interviews)

- without in-person visits of the city/ hospital/program or social events before or after interview day

- with an all-virtual interview day.

To find information on individual residency programs, the APGO website lists the FREIDA and APGO Residency Directories, which are not apps. Students are also aware of the Doximity Residency Navigator, which does include an app. The NRMP MATCH PRISM app is another resource, as it provides students with a directory of residency programs and information about each program.
The American College of Obstetricians and Gynecologists (ACOG) recognizes that residency program websites and social media will be crucial in helping applicants learn about individual programs, faculty, and residents. As such, ACOG hosted a Virtual Residency Showcase in September 2020 in which programs posted content on Instagram and Twitter using the hashtag \#ACOGResWeek20. ${ }^{2}$ Similarly, APGO and CREOG produced a report containing a social media directory, which lists individual residency programs and whether or not they have a social media handle/account. ${ }^{3}$ In a recent webinar, ${ }^{4}$ Drs. Sarah Santiago and Elizabeth Southworth noted that the number of residency programs that have an Instagram account more than doubled (from 60 to 128) between May and September 2020.

We present 2 tables describing the important features and caveats of apps available to students to assist them with residency applications this year-TABLE 1 summarizes apps to aid with applications and interviews; TABLE 2 lists apps designed for students to learn more about individual residency programs. We wish all of this year's students every success in their search for the right program. 


\begin{tabular}{|c|c|c|c|}
\hline App & Platform & Important features & Caveats \\
\hline $\begin{array}{l}\text { Residency Navigator on the } \\
\text { Doximity app }\end{array}$ & $\begin{array}{l}\text { Free app available } \\
\text { for iOS and Android }\end{array}$ & $\begin{array}{l}\text { Includes: } \\
\text { - Ratings and reviews from } \\
\text { current residents and alumni } \\
\text { - Program information about } \\
\text { top feeder schools and } \\
\text { alumni destinations } \\
\text { - Easy search function for } \\
\text { programs by specialty and } \\
\text { location } \\
\text { - Filtering of programs by } \\
\text { hospital type, intended } \\
\text { fellowship, training } \\
\text { environment } \\
\text { - Creation of a list of favorite } \\
\text { programs } \\
\text { - User can add free-text notes } \\
\text { about program }\end{array}$ & $\begin{array}{l}\text { - Information about programs } \\
\text { is collected by residents and } \\
\text { alumni from surveys } \\
\text { - Large systems with multiple } \\
\text { residency programs can } \\
\text { have inaccurate information } \\
\text { about top feeder schools, } \\
\text { resident and alumni informa- } \\
\text { tion, and board passage } \\
\text { rates }\end{array}$ \\
\hline $\begin{array}{l}\text { The MATCH PRISM app, by } \\
\text { the National Resident } \\
\text { Matching Program (NRMP) }\end{array}$ & $\begin{array}{l}\text { Free app available } \\
\text { for iOS and Android }\end{array}$ & $\begin{array}{l}\text { Includes tabs with: } \\
\text { - Residency match schedule } \\
\text { of events } \\
\text { - Directory of all residency } \\
\text { programs participating in } \\
\text { The Match with direct links } \\
\text { to programs } \\
\text { - } 20 \text {-factor rating system to } \\
\text { aid in program selection } \\
\text { - Easy search function to } \\
\text { locate programs by specialty } \\
\text { and location } \\
\text { - User free-text notes about } \\
\text { program }\end{array}$ & $\begin{array}{l}\text { - Cannot schedule interviews } \\
\text { with programs } \\
\text { - Cannot submit NRMP rank } \\
\text { list }\end{array}$ \\
\hline Instagram & $\begin{array}{l}\text { - Free app available } \\
\text { for iOS and Android }\end{array}$ & $\begin{array}{l}\text { Accounts are managed by } \\
\text { the residency programs and } \\
\text { updated frequently } \\
\text { Offers an inside look to } \\
\text { happenings within each } \\
\text { program - social, advocacy, } \\
\text { wellness, research, etc }\end{array}$ & $\begin{array}{l}\text { - Out of } 241 \text { ObGyn resi- } \\
\text { dency programs, only } 155 \\
\text { programs have Instagram } \\
\text { accounts } \\
\text { - Users must search for } \\
\text { programs by keywords or } \\
\text { hashtags }\end{array}$ \\
\hline Twitter & $\begin{array}{l}\text { - Free app available } \\
\text { for iOS and Android }\end{array}$ & $\begin{array}{l}\text { - Accounts are managed by } \\
\text { the residency program } \\
\text { - App offers an inside look } \\
\text { to happenings within the } \\
\text { program - social, advocacy, } \\
\text { wellness, research, etc } \\
\text { - Programs post updates } \\
\text { frequently }\end{array}$ & $\begin{array}{l}\text { - Out of } 241 \text { ObGyn residency } \\
\text { programs, only } 66 \text { programs } \\
\text { have Twitter accounts } \\
\text { - Users must search for } \\
\text { programs by keywords or } \\
\text { hashtags }\end{array}$ \\
\hline
\end{tabular}

\section{References}

1. Association of Professors of Gynecology and Obstetrics, Council on Resident Education in ObGyn. Updated APGO and CREOG Residency Application Response to COVID-19. https://www.apgo.org/wp-content/uploads/2020/05 /Updated-APGO-CREOG-Residency-Response-to -COVID-19-.pdf. Accessed October 27, 2020.

2. https://www.acog.org/education-and-events/webinars /virtual-residency-showcase. Accessed October 4, 2020.

3. Social media directory-ObGyn. https://docs.google.com
/spreadsheets/d/e/2PACX-1vQ6boyn7FWV9tEhfQplo3 XJgNIPNBQ3qCYf4IpV-rOPcd212J-HNR84p0r85nXrAz MvOmcNlgjywDP/pubhtml?gid=1472916499\&single =true. Accessed October 27, 2020.

4. APGO webinar: Virtual interviews best practices. September 9, 2020. https://zoom.us/rec/play/KqxMT6Wnb F6qaMnFMoer_czOszRGRT89o364GHDzhFpjXodgSyGZpj 0BaCvKnXtxD7IH-ulIU4QIzHBT.etDUC4znlfNcgG7T?start Time $=1599696020000$. Accessed October 4, 2020. 